\title{
Wspomnienie o Profesorze Jerzym Kulczyckim
}

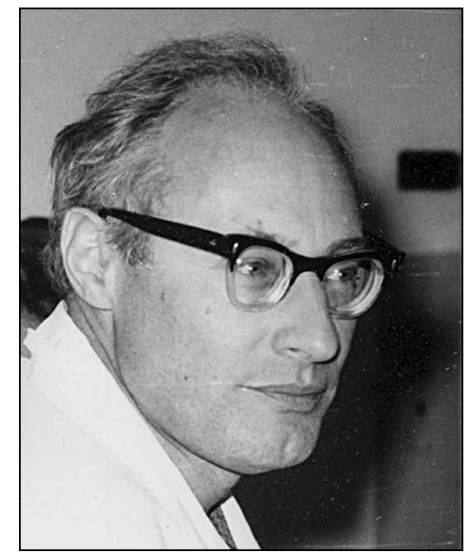

Profesor Jerzy Kulczycki urodził się we Lwowie 24 maja 1928 roku. Od roku 1930 mieszkał wraz z Rodzicami w Skierniewicach. W 1947 roku zdał egzamin maturalny. W czasie okupacji, w latach 1943-1945, należał do Armii Krajowej (Obwód Sroka). Jego Ojciec w tym czasie był oficerem Wojska Polskiego w Afganistanie, a następnie w Wielkiej Brytanii. Fakt ten przez 2 lata uniemożliwiał młodemu maturzyście wstęp na studia lekarskie. W tej sytuacji ukończył początkowo 2 lata studiów w Wyższej Szkole Higieny Psychicznej w Warszawie, a studia medyczne rozpoczął dopiero w 1949 roku w Szczecinie. Od 2. roku studiów pracował w Zakładzie Histologii i Embriologii, którego kierownikiem był prof. Jan Słotwiński. Początkowo pełnił funkcję demonstratora, następnie był zastępcą asystenta, a potem asystentem. Po uzyskaniu dyplomu lekarza w 1954 roku rozpoczął pracę w Klinice Neurologii Pomorskiej Akademii Medycznej. W 1962 roku uzyskał tytuł specjalisty w zakresie neurologii. Od początku pracy w Klinice Neurologii poza neurologią interesowat się neuropatologią. Zorganizował Pracownię Neuropatologiczną, w której wykonał wiele badań będących podstawą jego licznych publikacji. W tym okresie odbył także staże z neuropatologii w In- stytucie Neuropatologii Uniwersytetu Humboldta w Berlinie oraz w Instytucie Psychiatrii i Neurologii w Budapeszcie. W 1973 roku uzyskał tytuł specjalisty w zakresie neuropatologii. Prowadził liczne badania neuropatologiczne ukierunkowane na choroby rozwojowe, naczyniowe i zwyrodnieniowe mózgu, Interesował się również problemem zwapnień śródmózgowych, między innymi wykonywał badania składu pierwiastkowego złogów w chorobie Fahra. Prowadzona przez Profesora Pracowania Neuropatologiczna w krótkim czasie została uznana za jedną z najlepszych w kraju, goszcząc wybitnych naukowców, między innymi prof. Mirosława Mossakowskiego, prof. Marię Dąmbską, prof. Sigvalda Refsuma i prof. Matti Haltię. W 1962 roku obronił pracę doktorską pt.: „Typy i analiza morfologiczna pierwotnych i wtórnych krwotoków do pnia mózgowego". Tytuł doktora habilitowanego uzyskał w 1971 roku po przedstawieniu rozprawy pt.: "Correlation of vascular changes and morphology of lacunae in the so-called cerebral lacunar state".

W latach 60. XX wieku, po nawiązaniu współpracy z prowadzoną przez prof. Sayka Kliniką Neurologiczną Uniwersytetu w Rostocku, Jerzy Kulczycki zorganizował na bazie Kliniki Neurologii PAM Pracownię Cytologii Płynu Mózgowo-Rdzeniowego. Sam skonstruował kamerę do przygotowania preparatów osadowych oraz prowadzit liczne badania, które stały się podstawą wielu prac doktorskich oraz habilitacyjnych. Badania wykonywane przez Profesora w połączeniu z szczegółową analizą stanu klinicznego chorych pozwoliły na utworzenie szerokiej bazy danych. Na podstawie zebranego materiału napisał rozdział na temat diagnostyki cytologicznej płynu mózgowo-rdzeniowego w pierwszym polskim podręczniku pt. „Podstawy neuropatologii” wydanym w 1981 
roku pod wspólną redakcją z dr Zofią Osuch. W 1988 roku opracowat i wydał po raz pierwszy w Polsce i jako jeden z czterech w Europie "Atlas cytologiczny płynu mózgowo-rdzeniowego".

W 1976 roku Jerzy Kulczycki objął stanowisko Kierownika I Kliniki Neurologii Instytutu Psychiatrii i Neurologii (IPiN) w Warszawie, ale jeszcze przez wiele lat po wyjeździe do Warszawy utrzymywał kontakty osobiste i naukowe ze Szczecinem. Nadal jako konsultant Pracowni Neuropatologicznej w Szczecinie prowadził liczne badania. W 1982 roku doc. Jerzy Kulczycki uzyskał tytuł profesora nadzwyczajnego, a w 1990 roku - tytuł profesora zwyczajnego.

W trakcie pracy w IPiN główne zainteresowania badawcze Profesora były ukierunkowane na problemy związane z objawami neuroinfekcji $w$ aspekcie zarówno klinicznym, jak i neuropatologicznym. Badania te dotyczyły dwóch rodzajów schorzeń o szczególnie niepomyślnym rokowaniu: podostrego stwardniającego zapalenia mózgu (SSPE, subacute sclerosing panencephalitis) oraz choroby Creutzfeldta-Jakoba (CJD, Creutzfeldt-Jakob disease).

Jako Kierownik I Kliniki Neurologii IPiN kierował projektem dotyczącym etiopatogenezy, przebiegu klinicznego oraz patomorfologii SSPE. W ramach projektu wykonywano między innymi badania poziomu przeciwciał przeciwodrowych oraz badania na obecność antygenu wirusa odry w limfocytach krwi obwodowej. W przypadku zgonu po uzyskaniu zgody rodziców lub opiekunów Prof. Kulczycki osobiście przeprowadzał szczegółowe badania neuropatologiczne mózgu. Rozpoczęte w Polsce badania kontynuował $w$ trakcie kilkumiesięcznego pobytu w Institute for Basic Research in Development Disabilities (Staten Island, NY), gdzie pracował nad wykrywaniem RNA wirusa w mózgu oraz oceną dynamiki zmian odporności komórkowej i humoralnej. Brał również udział w badaniach patomorfologicznych mózgu osób zmarłych z powodu choroby CJD. Wyniki tych badań przedstawiono w 6 publikacjach, które ukazały się w Stanach Zjednoczonych w renomowanych czasopismach anglojęzycznych. Po powrocie do kraju Profesor Jerzy Kulczycki, we współpracy z Państwowym Zakładem Higieny, zorganizował ogólnopolskie badania epidemiologiczne CJD, które na światowym sympozjum w Bergamo uznano za najlepiej przeprowadzone na świecie. $W$ badaniach tych wykazano istotny pozytywny wpływ szczepień przeciwodrowych na zmniejszenie rozpowszechnienia SSPE. Dzięki pracom Profesora uporządkowano w Polsce profilaktykę szczepień odrowych. Duże zaangażowanie Profesora w edukację społeczną oraz organizację szczepień spowodowały, że SSPE w populacji polskiej przeszło w pierwszej dekadzie XXI wieku do historii.

Równolegle od 1995 roku Profesor Kulczycki prowadził badania epidemiologiczne, kliniczne i neuropatologiczne w ramach międzynarodowego grantu subwencjonowanego przez Komisję Europejską. Prowadzone badania pozwoliły na dokładną charakterystykę tej choroby, ocenę ryzyka jej występowania, określenie zasad diagnostyki oraz obrazu morfologicznego zmian w mózgu.

Pracując w IPiN, Profesor Kulczycki bardzo interesował się neuroradiologią, sam opisywał wyniki wielu badań neuroobrazowych, osobiście wykonywał wiele badań, w tym angiografię, mielografię. Był współautorem książki: „Współczesna diagnostyka wizualna ośrodkowego układu nerwowego".

Profesor Jerzy Kulczycki był wybitnym nauczycielem akademickim. W latach 1972-1976 pełnił funkcję prodziekana Wydziału Lekarskiego PAM w Szczecinie. Za swoje zasługi otrzymał tytuł doktora honoris causa Pomorskiej Akademii Medycznej.

Profesor był bardzo dobrym dydaktykiem. Swoją rozległą wiedzę umiejętnie przekazywał słuchaczom, rozbudzając ich zainteresowania. Jego wykłady zawsze cieszyły się dużym zainteresowaniem. Można śmiało powiedzieć, że Profesor Jerzy Kulczycki był wychowawcą całego pokolenia neurologów. Przez ponad 15 lat prowadził coroczne konferencje szkoleniowe dla ordynatorów oddziałów neurologicznych z całego kraju, które cieszyły się bardzo dużym uznaniem. Materiały z tych konferencji, wydawane przy współpracy z Centrum Medycznym Kształcenia Podyplomowego, były podstawą kształcenia podyplomowego, w tym szkolenia specjalizacyjnego. 
Profesor Jerzy Kulczycki od początku swojej pracy zawodowej był członkiem Polskiego Towarzystwa Neurologicznego (PTN), a ponad 25 lat był członkiem Zarządu Głównego PTN. Ponadto był członkiem Stowarzyszenia Neuropatologów Polskich oraz Szczecińskiego Towarzystwa Naukowego. Przez 26 lat, od 1977 do 2003 roku, pełnił funkcję Redaktora Naczelnego czasopisma „Neurologia i Neurochirurgia Polska”, głównego pisma naukowego PTN. Był również Redaktorem Działu Neurologicznego czasopisma „Postępy Psychiatrii i Neurologii”.

Za swoją działalność został odznaczony między innymi Krzyżem Oficerskim Orderu Odrodzenia Polski, Złotym Krzyżem Zasługi, Krzyżem Armii Krajowej, a także Odznaką Gryfa Pomorskiego.
Profesor Jerzy Kulczycki był wspaniałym lekarzem, wybitnym, doświadczonym specjalistą z zakresu neurologii i neuropatologii, uznanym w kraju i za granicą ekspertem z zakresu cytologii płynu mózgowo-rdzeniowego, diagnostyki CJD i SSPE. Był człowiekiem o szerokich zainteresowaniach pozamedycznych. Pisał limeryki, interesował się historią i fotografiką. Był lubiany i powszechnie szanowany.

Odszedł od nas wspaniały człowiek, wybitny lekarz neurolog, neuropatolog i neuroradiolog. Badacz zawsze otwarty na nowe idee, nowe koncepcje i nowe wyzwania. Człowiek o wielkim autorytecie. Będzie nam brakowało jego pogody ducha, życzliwości, niezwykłej kultury i uroku.

Danuta Ryglewicz Przemysław Nowacki 
